Journal of Human Evolution

doi: 10.1016/j.jhevol.2017.03.003

\title{
Direct radiocarbon dating and DNA analysis of the Darra-i-Kur (Afghanistan) human temporal bone
}

Katerina Douka ${ }^{1+}$, Viviane Slon ${ }^{2+}$, Chris Stringer ${ }^{3}$, Richard Potts ${ }^{4}$, Alexander Hübner ${ }^{2}$, Matthias Meyer ${ }^{2}$, Fred Spoor ${ }^{5,6}$, Svante Pääbo ${ }^{2}$ and Tom Higham ${ }^{1}$

1. Oxford Radiocarbon Accelerator Unit, Research Laboratory for Archaeology and the History of Art, University of Oxford, Oxford OX1 3QY, United Kingdom.

2. Department of Evolutionary Genetics, Max Planck Institute for Evolutionary Anthropology, Leipzig, Germany.

3. The Natural History Museum, Cromwell Road, London SW7 5BD, United Kingdom.

4. Human Origins Program, National Museum of Natural History, Smithsonian Institution, Washington, DC, 20560, U.S.A.

5. Research Department of Cell and Developmental Biology, University College London, London, U.K.

6. Department of Human Evolution, Max Planck Institute for Evolutionary Anthropology, Leipzig, Germany.

${ }^{+}$contributed equally to the manuscript.

\begin{abstract}
The temporal bone discovered in the 1960s from the Darra-i-Kur cave in Afghanistan is often cited as one of the very few Pleistocene human fossils from Central Asia. Here we report the first direct radiocarbon date for the specimen and the genetic analyses of DNA extracted and sequenced from two areas of the bone. The new radiocarbon determination places the find to $\sim 4500 \mathrm{cal}$ BP ( $2500 \mathrm{BCE})$ contradicting an assumed Palaeolithic age of $\sim 30,000$ years, as originally suggested. The DNA retrieved from the specimen originates from a male individual who carried mitochondrial DNA of the modern human type. The petrous part yielded more endogenous ancient DNA molecules than the squamous part of the same bone. Molecular dating of the Darra-i-Kur mitochondrial DNA sequence corroborates the radiocarbon date and suggests that the specimen is younger than previously thought. Taken together, the results consolidate the fact that the human bone is not associated with the Pleistocene-age deposits of Darra-i-Kur; instead it is intrusive, possibly re-deposited from upper levels dating to much later periods (Neolithic). Despite its Holocene age, the Darra-i-Kur specimen is, so far, the first and only ancient human from Afghanistan whose DNA has been sequenced.
\end{abstract}

Keywords : Darra-i-Kur; Middle Palaeolithic; Central Asia; Neanderthals; radiocarbon dating; ancient DNA

Introduction 
The site of Darra-i-Kur (Cave of the Valley; other spellings include Darra-e Kūr; Bābā Darwish is another name of the site) in Afghanistan first came to prominence in the late 1950s with fieldwork and extensive site surveys that were undertaken by a team of researchers from the American Museum of Natural History (NYC) and the National Museum of Afghanistan (Kabul). Louis Dupree and Abdul Rauf Wardak (Dupree 1972a) surveyed limestone foothills in northern Afghanistan and recorded more than 100 caves. In the Badakhshan province, near the village of Chinār-i Gunjus Khān $\left(36^{\circ} 44^{\prime} \mathrm{N}, 6^{\circ} 59^{\prime} \mathrm{E}\right)$ (Figure 1) they identified a cave called Darra-i-Kur as potentially promising, after finding Mousterian-like flakes eroding on the talus slopes leading to the site. Subsequently, in 1966, the site was excavated and three trenches were dug. The first, Trench 1, with prominent Neolithic finds, was $2.5 \mathrm{~m}$ wide and reached bedrock $\sim 1 \mathrm{~m}$ down at one end, while at the other end there was a large roof fall. A second trench was then excavated in order to avoid the roof fall debris. This was $4 \mathrm{~m}$ in length, $2.5 \mathrm{~m}$ in width and reached $2.5 \mathrm{~m}$ depth before the bedrock was encountered. A third trench was the largest ( $2.5 \mathrm{~m}$ wide and $24 \mathrm{~m}$ in length) and extended out of the cave down the talus slope and into deposits supposedly derived from the action of a nearby stream. According to Dupree (1972b) periodic flooding may have been responsible for mixing some of the hearth-related charcoal material found at the site with overlying silts.

The lithic industry of the site comprised implements and debitage made of locally available, poor-quality flint or chert. More than 800 implements, predominantly using Levallois techniques, were recovered (Dupree and Davis, 1972). The lithics included crude Levallois points (see Costa, 2012) and flakes, handaxes, scrapers and flake-blades, and were attributed to the Middle Palaeolithic (Mousterian). Neolithic and Iron Age implements were also found in the sequence toward the upper sections, as well as Late Islamic and modern $20^{\text {th }}$ century material.

The excavators identified enough charcoal for radiocarbon dating, found in association with the Middle Palaeolithic flake implements and cores. Radiocarbon dating was undertaken at the GeoChron Laboratories (Cambridge, Massachusetts, USA) in the early 1970s. However, the laboratory was compelled to amalgamate the charcoal and soil material in order to get enough carbon for dating using a conventional system. The radiocarbon date, produced on total carbon, GX-1122: 30,300 +1900/-1200 BP (Dupree, 1972b), must be looked at very critically; it is almost certainly a minimum age as the radiocarbon laboratory noted at the time (Krueger pers. comm. in Dupree, 1972b) and echoed by others since (Stringer and Burleigh, 1981).

\section{The human fossil}

Angel (1972) described a fragmentary human right temporal bone discovered at the Mousterian level of the site (Cut LC 11:200) (Figure 2). The bone comprised the tympanic and petrosal bones, with the mastoid process and paramastoid crest broken at the base. Angel (1972) compared measurements of the temporal and, specifically, the tympanic bone, which was quite well-preserved, against anatomically modern human and Neanderthal equivalents and suggested that the temporal sat closer to moderns than Neanderthals. In particular, he emphasized that due to the flatness of the tympanic bone and most other features, with the exception of the very large internal auditory meatus and slightly lateral location of the stylomastoid foramen, the temporal bone was modern in 
appearance. Assuming an age that overlapped with that of Neanderthals, Angel cautiously suggested that the Darra-i-Kur temporal could be transitional to modern humans rather than a Neanderthal. Bricker (1976) urged caution about inferring too much from the remains due to the fragmentary nature of the find. Arensburg et al. (1981) included the Darra-i-Kur fossil in their study of 140 middle ear bones belonging to three different populations of modern humans and concluded that there was a general homogeneity observed in their results, regardless of antiquity. More recently, in their study of the ossicular chain of La Ferrassie 3, Quam et al. (2013) found that the Darra-i-Kur specimen fell within, but towards the upper end, of the recent $H$. sapiens range of variation.

The Darra-i-Kur temporal bone is mentioned in various publications because it stands out as one of the very few human remains recovered from this period in Central Asia. It is regularly referred to by a range of authors and in a variety of studies revolving around human palaeoanthropology and palaeoenvironments of Asia (e.g., Lindly and Clark, 1990; Trinkaus, 2005; Jaubert et al., 2006; Sonakia and de Lumley, 2006; Glantz et al., 2008a; 2008b; Malassé and Gaillard, 2011; Reyes-Centeno, 2016).

Given doubts regarding the precise age and skeletal attribution of the specimen, we decided to test it for the first time by direct dating and by DNA analysis. The bone [Catalog number: NMNH 387961] is housed in the Smithsonian National Museum of Natural History in Washington (DC). We obtained permission for destructive sampling in 2014.

\section{Methods and materials}

\section{Sampling procedure}

Prior to sampling, the temporal bone was CT scanned to document the morphology for future research and to plan the most appropriate locations from which to take samples. The CT images were acquired using the Skyscan 1173 (Bruker, Belgium) at the Department of Human Evolution, Max Planck Institute for Evolutionary Anthropology, Leipzig. Key scan and reconstruction parameters include $130 \mathrm{kV}, 61 \mathrm{uA}$, and a $0.025 \mathrm{~mm}$ voxel size. For use in the context of this study the latter was resampled to $0.100 \mathrm{~mm}$. The CT image stack was analysed using Avizo 7.1 (Visualization Sciences Group).

The three key criteria in the selection of the sampling locations were: (1) target dense bone as it has been shown to yield a relatively higher proportion of endogenous DNA (Pinhasi et al., 2015); (2) avoid features that provide morphologically and taphonomically important information; and (3) avoid sampling the edges of the specimen, so that these can always be matched should more pieces of the cranium be found in future excavations. Given that both the external and internal morphology of the temporal bone is distinct in anatomically modern humans and Neanderthals (Harvati, 2003; Spoor et al., 2003), particular care had to be taken to avoid phylogenetically relevant features. For the first sample used for DNA analysis, the densest bone of the specimen was targeted, which can be found internally in the otic capsule surrounding the bony labyrinth of the inner ear. The CT scans showed that the otic capsule posteromedially to the posterior semicircular canal has a thickness of up to $4 \mathrm{~mm}$, sufficient to be sampled without damaging the canal itself (Figure $3 \mathrm{~b}$ ). The latter was critical because the spatial relationship between the arcs of the posterior and lateral semicircular canals is a feature that diagnostically distinguishes modern humans and Neanderthals (Spoor et al., 2003). The sampling was planned by doing a 'virtual trial' in 
which a hole was simulated using a 3D visualization of the temporal bone (Figure 3a). The hole reaches superiorly from the roof of the jugular fossa, in parallel with and medioposterior to the plane of the posterior semicircular canal. The temporal bone visualization with simulated hole was 3D printed at natural size. Using this model as guidance, the actual hole was drilled under a binocular microscope using $1.0 \mathrm{~mm}$ dental drills (H1SX-010-RA, NTI-Kahla, Germany). The cortical bone in the jugular fossa was drilled and disposed of, and a $53.0 \mathrm{mg}$ sample (sample A) was obtained from the otic capsule superiorly.

For the second sample used for DNA analysis and dating, the temporal squama superior to the anterior petrosal surface was targeted (Figure 3c). In this area the middle of the squama is pneumatized by air cells, but the cortical bone laterally and medially is sufficiently thick for sampling $(1.5-2.5 \mathrm{~mm})$. Before sampling, the external surface on either side was removed using $1 \mathrm{~mm}$ dental drills. Subsequently a hole was drilled centrally through the targeted area, and expanded radially, leaving the superior margin of the squama intact. A $586.4 \mathrm{mg}$ sample (sample B) could thus be collected.

\section{AMS radiocarbon dating and stable isotope analysis}

Sample B was dated in the Oxford Radiocarbon Accelerator Unit (ORAU), University of Oxford, using the standard method for pretreating bone samples. This involved the demineralisation of the bone matrix using an $\mathrm{HCl}$ step, followed by a $\mathrm{NaOH}$ and a second $\mathrm{HCl}$ wash. The gelatinized extract underwent ultrafiltration for the removal of low molecular weight contaminants and other impurities. The sample was then combusted, converted to gas and its stable isotopes measured in a CHN elemental analyser, operating in continuous flow mode using an He carrier gas linked with a Europa IRMS. The $\mathrm{CO}_{2}$ was graphitized and its radiocarbon content was measured using the Oxford HVEE Accelerator Mass Spectrometer (for a detail description of the pretreatment method see Brock et al., 2010).

\section{DNA extraction, library preparation and sequencing}

We used $15.2 \mathrm{mg}$ of bone powder from sample A and 17.0mg from sample B as input for DNA extraction (Dabney et al., 2013; Korlevic et al., 2015). Thirty percent of each DNA extract (Supplementary Online Material [SOM] Table S1) was converted into a singlestranded DNA library (Gansauge and Meyer, 2013; Korlevic et al., 2015) tagged with a pair of unique indexes (Dabney and Meyer, 2012; Kircher et al., 2012; Korlevic et al., 2015). The number of DNA molecules in the libraries was determined by digital droplet PCR (Slon et al., 2016). 1 $\mu$ g of each library was enriched for human mitochondrial (mt) DNA sequences ( Maricic et al., 2010; Fu et al., 2013a). Sequencing was performed on a MiSeq (Illumina) instrument. Details on the processing of sequencing data are provided in the SOM.

\section{Results and discussion}

Radiocarbon dating and stable isotope analysis 
We used $490 \mathrm{mg}$ of bone powder and obtained $29.4 \mathrm{mg}$ of collagen, a yield of $6 \%$ by weight. This indicates a reasonably well-preserved bone, which initially raised suspicions that it might be younger than anticipated. All other analytical data routinely collected (C:N atomic ratio: 3.2; \%C on combustion: 42.6) was within expected ranges. AMS ${ }^{14} \mathrm{C}$ dating of the Darra-i-Kur sample produced a conventional radiocarbon age of $3989 \pm 31$ BP (OxA31781). When calibrated using the latest INTCAL13 calibration curve (Reimer et al., 2013) and OxCal v4.2 software (Bronk Ramsey, 2009) this converts to an age ranging between $4530-4410$ cal BP/ $2580-2460$ BCE at $95.4 \%$ probability.

This radiocarbon determination is much younger than the conventional date on charcoal (GX-1122, 30 ka BP) suggesting that the human bone was intrusive in the Mousterian layer. In fact, the layer just above, described by Dupree (1972a) as a "Goat Cult" Neolithic, was also dated in the early 1970s at $3780 \pm 130$ BP (GX-0910), a determination statistically identical to the new AMS date we report here. Very importantly, the Neolithic layer also contained human remains consisting of skull fragments and several long bones of one or two children (Dupree 1972a). We may assume therefore that the temporal bone belongs to the overlying Neolithic layer of the site and possibly relates to the other human individual(s) discovered there.

In addition to dating, the ratios of stable carbon ${ }^{13} \mathrm{C} /{ }^{12} \mathrm{C}$, the $\delta^{13} \mathrm{C}$ value) and nitrogen $\left({ }^{15} \mathrm{~N} /{ }^{14} \mathrm{~N}\right.$, the $\delta^{15} \mathrm{~N}$ value) were measured at $-19.0 \%$ and $\delta^{15} \mathrm{~N}: 12.3 \%$, respectively. $\delta^{13} \mathrm{C}$ values are reported in \%o with reference to VPDB (Coplen, 1994), $\delta^{15} \mathrm{~N}$ values with respect to AIR, while analytical precision is \pm 0.2 and $\pm 0.3 \%$ respectively. These values are consistent with other isotopic results from humans dating to a similar period in Central Asia (e.g., Lightfoot et al. 2015).

\section{DNA preservation in the Darra-i-Kur temporal bone}

To evaluate the preservation of DNA molecules in the Darra-i-Kur temporal bone, we compared the output of shallow shotgun sequencing of the library prepared from the petrous part (sample A) to that prepared from the squama (sample B) (SOM Table S2). $0.8 \%$ of sequences longer than 35 bases originating from sample A could be mapped to the human reference genome, compared to only $0.1 \%$ of sequences originating from sample $B$. By multiplying the fraction of sequences that mapped to the reference genome by the number of DNA molecules in a library, we extrapolated the number of sequences from different DNA fragments that would be yielded had the library been sequenced to exhaustion. We estimate that the library prepared from sample A contains $3.93^{*} 10^{6}$ such human DNA fragments per mg of bone powder, approximately 11 times more than the library prepared from sample B $\left(3.54 * 10^{5}\right.$ fragments).

Ancient DNA molecules can be distinguished from present-day contamination based on the presence of a specific type of nucleotide misincorporation. Cytosine $(\mathrm{C})$ bases at the end of DNA molecules tend to undergo deamination, resulting in uracil residues, which are read by DNA polymerases as thymine (T) bases. When aligning sequences to a reference genome, this damage can be recognized as a $\mathrm{C}$ to $\mathrm{T}$ substitution, which characteristically occurs at or near the ends of ancient DNA fragments (Briggs et al., 2007; Krause et al., 2010; Sawyer et al., 2012). In both libraries prepared from the Darra-i-Kur specimen, there is an elevated frequency of $\mathrm{C}$ to $\mathrm{T}$ changes at the ends of molecules: $16.1 \%$ and $17.4 \%$ of Cs in the reference genome appear as Ts at the 5'- and 3'-end of sequences from sample A and $5.0 \%$ and $7.1 \%$ of sequences from sample B (SOM Table S2, SOM Figure S1), suggesting the 
presence of ancient DNA molecules in the libraries. These terminal $\mathrm{C}$ to $\mathrm{T}$ frequencies are significantly higher ( $p$-value $=1.442^{*} 10^{-15}$ and $p$-value $=2.159^{*} 10^{-12}$ for the $5^{\prime}$ - and $3^{\prime}$ - ends, respectively) for sequences originating from sample A than from sample B.

When filtering in silico for sequences likely to be of ancient origin based on the presence of a $\mathrm{C}$ to $\mathrm{T}$ change on one end, the frequency of $\mathrm{C}$ to $\mathrm{T}$ substitutions on the other end increases (SOM Table S2), indicating that the libraries contain a mixture of ancient and modern DNA fragments (Meyer et al., 2014). We retained 466 sequences with a terminal $\mathrm{C}$ to $\mathrm{T}$ substitution from sample A and 89 such sequences from sample B, constituting $0.043 \%$ and $0.002 \%$ of sequences in each respective library that show evidence of being derived from authentic ancient DNA fragments. We estimate that if sequenced to exhaustion, approximately 33-times more sequences showing a terminal $\mathrm{C}$ to $\mathrm{T}$ substitution would be yielded from sample A than from sample B (SOM Table S2).

Thus, in concurrence with previous studies showing that the dense part of the petrous bone preserves ancient DNA particularly well (Gamba et al., 2014; Pinhasi et al., 2015), we find that for the Darra-i-Kur specimen, the petrous part yielded substantially more endogenous ancient DNA fragments than the squamous part of the same temporal bone.

\section{Sex determination based on genetic data}

To determine the sex of the Darra-i-Kur individual, we combined the sequences from the two libraries and compared the coverage of the $\mathrm{X}$ chromosome to the coverage of the autosomes. To mitigate the influence of present-day contamination, we limited this analysis to sequences carrying a terminal $\mathrm{C}$ to $\mathrm{T}$ substitution to the reference genome (Meyer et al., 2014). Congruent with the morphological analysis (Angel, 1972), the $X$ to autosome coverage ratio of 0.50 indicates that the Darra-i-Kur individual was a male.

In sequencing data originating from a male individual, an excess of fragments mapping to the $\mathrm{X}$ chromosome is indicative of contamination by female DNA. When including all sequences in the analysis, the female contamination estimate (see SOM ) is significantly lower $\left(p\right.$-value $\left.=1.29^{*} 10^{-4}\right)$ for sequences originating from sample A $(10.7 \%)$ than from sample B (29.7\%).

\section{The Darra-i-Kur mitochondrial genome sequence}

To reconstruct the mtDNA genome sequence of the Darra-i-Kur individual (see SOM ), we combined sequences from the two libraries enriched for mtDNA fragments and used a consensus calling software that takes into account the characteristics of ancient DNA, i.e., terminal $\mathrm{C}$ to $\mathrm{T}$ substitutions and shorter sequence length, to separate endogenous ancient sequences from contaminating ones (Renaud et al., 2015). The 47,386 mtDNA fragments produced from the Darra-i-Kur specimen yielded an average mtDNA coverage of 181.9fold.

The mtDNA sequence of Darra-i-Kur was compared to those of present-day and ancient humans, Neanderthals, Denisovans and a Middle Pleistocene hominin (Sima de los Huesos) (SOM Table S3) to determine to which hominin group it should be attributed. We find that the mtDNA of Darra-i-Kur is of the modern human type (Figure 4a). It pertains to haplogroup H2a, a subclade of an mtDNA haplogroup estimated to have diverged from a shared common ancestor with other haplogroups only 23,900 years ago (Fu et al., 2013b) and that still exists in European and Central Asian populations today (Loogvali et al., 2004). 
Molecular dating of the Darra-i-Kur mtDNA sequence, using the mtDNAs of 10 other directly radiocarbon-dated ancient modern humans (SOM Table S3) as calibration points, yielded a tip date ranging between 12 and 31,587 years (Figure $4 \mathrm{~b}$ ). Thus, the results of the mtDNA analysis also contradict the previously published age estimate $(\sim 30,000$ years $)$ for this individual (Dupree, 1972b).

\section{Archaeological implications}

Despite covering a vast area of over four million $\mathrm{km}^{2}$ that bridges western and eastern Eurasia, Central Asia is extremely poor in palaeoanthropological remains from the Middle and Late Pleistocene.

The elimination of the Darra-i-Kur temporal bone from the Pleistocene fossil record of Central Asia means that of the handful of presumably Pleistocene-age humans, none can be attributed securely to early $H$. sapiens (possibly with the exception of the recently discovered premolar from Kul'bulak). We know, however, that modern humans reached west Siberia by $\sim 45,000$ years ago based on the evidence from Ust-Ishim (Fu et al., 2014), before arriving in Europe, possibly having crossed Central Asia first. Regrettably, the archaeological record of the region for this important period is mute. The Early Upper Palaeolithic is underrepresented and evidence of it remains patchy and poorly understood, despite the growing number of, largely undated, sites with lithic assemblages attributed to the period (e.g., Shugnou and Kharkush in Tajikistan, Kul'bulak, Dodekatym-2 and KyzylAlma-2 in Uzbekistan, Maibulak in Kazakhstan, Kara Kamar in northern Afghanistan) (Ranov et al., 2012; Kolobova et al., 2013 for some recent work and discussion).

Despite showing that the temporal bone from the Mousterian layer of Darra-i-Kur is of Holocene age, the character of the lithic assemblage it was found associated with is not questioned. In fact, Middle Paleolithic -often Levallois Mousterian- lithic assemblages have been found at several sites in Central Asia (and southern Siberia), strongly supporting the presence of Neanderthals in the region (e.g., Vishnyatsky, 1999; Derevianko et al., 2013). From a palaeoanthropological perspective, Neanderthal fossils are more numerous and better represented in the record. The most famous specimen is the Teshik-Tash child from Uzbekistan (Gremiatsky, 1949). Until about a decade ago, it was thought to represent the easternmost extent of the Neanderthal range. However, extraction and amplification of genetic material from three human bones found in the Okladnikov Cave in Siberia (Krause et al., 2007) revealed that they carried Neanderthal mtDNA, therefore stretching this range $2000 \mathrm{~km}$ further to the east. In the same study, the Neanderthal affinities of the TeshikTash child were also confirmed with retrieval and analysis of mtDNA from the left femur of the skeleton (Krause et al., 2007). Since then, further Neanderthal remains have been identified in Siberia, at Chagyrskaya and Denisova caves (Mednikova, 2013, Buzhilova, 2013, Prüfer et al., 2014). The human remains from a single juvenile from Obi-Rakhmat Grotto in Uzbekistan were considered originally to show a mosaic of Neanderthal and modern human traits (Glantz et al., 2004); Bailey et al. (2008), however, suggested that the dentition is essentially Neanderthal. The Sel'-Ungur teeth from Kyrgyzstan originally attributed to pre-Neanderthal forms are non-human (Glantz, 2010), while a fifth metatarsal from Anghilak and the Khudji deciduous incisor could not be attributed to a specific human (Glantz et al., 2008b, Trinkaus et al., 2000).

This is not the first time that the assumed Pleistocene age of a human fossil has been proven wrong on the basis of direct dating and DNA analysis. Using similar methodologies 
to the ones we used here, Benazzi et al. (2014) showed that the human remains from San Bernardino cave in Italy, previously attributed to Neanderthals, belong instead to recent (14 ${ }^{\text {th }}$ c. AD) H. sapiens, most likely incorporated in the Mousterian deposits of the site during historic times. Along similar lines, the presumed late surviving Neanderthals from Riparo Mezzena were shown to belong to Neolithic humans (Talamo et al., 2016). Likewise, Conard et al. (2004) and Street et al. (2006) have shown that a large corpus of the German palaeoanthopological record, previously assumed to be Pleistocene in age, was instead of Holocene age.

Lastly, we also note that despite its Holocene age, the Darra-i-Kur specimen is so-far the only ancient human from Afghanistan whose DNA has been sequenced. Future genetic studies on this specimen may shed light on the ancestry of Holocene populations in the region and their genetic affinity to other ancient and present-day populations.

\section{Conclusions}

We demonstrate here that $\mu \mathrm{CT}$ scans of temporal bones can be used to plan targeted sampling of an area likely to contain a relatively high amount of ancient endogenous DNA, while avoiding damage to the surrounding morphologically valuable features. Based on new radiocarbon dating and DNA analysis, the Darra-i-Kur temporal bone is clearly not a Palaeolithic-aged specimen. Instead, it is a much later human bone that appears to have been reworked down the stratigraphic sequence from the Neolithic deposit of the site. Its association with the Middle Palaeolithic archaeological remains at the site cannot be sustained. The specimen ought to be removed from discussions revolving around the fossil and archaeological record of late Pleistocene Central Asia.

\section{Accession information}

Sequencing data generated from the Darra-i-Kur specimen and negative controls were deposited in the Sequence Read Archive under BioProject ID PRJNA335708. The Darra-iKur mtDNA sequence was deposited in GenBank with accession code KX638446.

\section{Acknowledgements}

We are grateful to David Hunt and Catherine Denial (National Museum of Natural History, Smithsonian Institution, Washington, D.C) for curatorial and research assistance and to Jean-Jacques Hublin, Heiko Temming and David Plotzki (Max Planck Institute for Evolutionary Anthropology, Leipzig) for facilitating the CT scanning. We also thank the staff of the Oxford Radiocarbon Accelerator Unit at the University of Oxford for their work on the dating. We thank Barbara Höber, Birgit Nickel and Antje Weihmann for their work in the ancient DNA laboratory; Gabriel Renaud and Udo Stenzel for raw sequence data processing; and Janet Kelso, Martin Petr and Kay Prüfer for their input on the genetic analyses. The dating part of this work received funding from the European Research Council under the European Union's Seventh Framework Programme (FP7/20072013)/ERC grant agreement $n^{\circ}$ [324139] "PalaeoChron" awarded to Professor Tom Higham. Chris Stringer's research is supported by the Calleva Foundation and the Human Origins Research Fund. The CT scanning, sampling and genetic analyses were funded by the Max-Planck Society. 


\section{References}

Angel, J.L. 1972. A Middle Paleolithic temporal bone from Darra-i-Kur, Afghanistan. In Dupree, L. (Ed.), Prehistoric Research in Afghanistan (1959-1966). Trans. Am. Phil. Soc. $62,54-56$.

Arensburg, B., Harell, M.,Nathan, H., 1981. The human middle ear ossicles: Morphometry, and taxonomic implications. J. Hum. Evol. 10, 199-205.

Bailey, S.E., Glantz, M., Weaver, T., Viola, B., 2008. The affinity of the dental remains from the Obi Rakhmat Grotto, Uzbekistan. J. Hum. Evol. 55, 238-248.

Benazzi, S., Peresani, M., Talamo, S., Fu, Q., Mannino, M.A., Richards, M.P., Hublin, J.-J., 2014. A reassessment of the presumed Neandertal human remains from San Bernardino Cave, Italy. J. Hum. Evol. 66, 89-94.

Bricker, H.M., 1976. Upper Palaeolithic archaeology. Ann. Rev. Anthropol 5, 133-148.

Briggs, A.W., Stenzel, U., Johnson, P.L., Green, R.E., Kelso, J., Prüfer, K., Meyer, M., Krause, J., Ronan, M.T., Lachmann, M., Pääbo, S., 2007. Patterns of damage in genomic DNA sequences from a Neandertal. Proc. Natl. Acad. Sci. 104, 14616-14621.

Brock, F., Higham, T., Ditchfield, P., Ramsey, C.B., 2010. Current pretreatment methods for AMS radiocarbon dating at the Oxford Radiocarbon Accelerator Unit (ORAU). Radiocarbon 52, 103-112.

Bronk Ramsey, C. 2009. Bayesian analysis of radiocarbon dates. Radiocarbon 51, 337-360.

Buzhilova, A.P., 2013. Dental remains from the Middle Paleolithic layers of Altai Cave sites. Archaeology, Ethnology and Anthropology of Eurasia 41, 55-65.

Conard, N.J., Grootes, P.M., Smith, F.H., 2004. Unexpectedly recent dates for human remains from Vogelherd. Nature 430, 198-201.

Coplen T.B., 1994. Reporting of stable hydrogen, carbon and oxygen isotopic abundances. Pure Appl.Chem. 66, 273-276.

Costa, A.G., 2012. Were there stone-tipped armatures in the South Asian Middle Paleolithic? Quatern. Int. 269, 22-30.

Dabney, J., Meyer, M., 2012. Length and GC-biases during sequencing library amplification: a comparison of various polymerase-buffer systems with ancient and modern DNA sequencing libraries. Biotechniques 52, 87-94.

Dabney, J., Knapp, M., Glocke, I., Gansauge, M.T., Weihmann, A., Nickel, B., Valdiosera, C., Garcia, N., Pääbo, S., Arsuaga, J.L., Meyer, M., 2013. Complete mitochondrial genome sequence of a Middle Pleistocene cave bear reconstructed from ultrashort DNA fragments. Proc. Natl. Acad. Sci. 110, 15758-15763.

Debetz, G. 1940. The anthropological features of the human skeleton from the cave of Teshik-Tash [in Russian]. Trudy Uzbekist. Fil. Akad. Nauk. 1, 46-49.

Derevianko A.P., Markin S.V, Shunkov M.V. 2013. The Sibiryachikha facies of the Middle Paleolithic of the Altai. Archaeology, Ethnology and Anthropology of Eurasia 41, 89103.

Dupree, L. (Ed.) 1972a. Prehistoric research in Afghanistan (1959-1966) Trans. Am. Phil. Soc., 62, 1-84.

Dupree, L. 1972b. Introduction: Outline of work by season. In Dupree, L. (ed) Prehistoric research in Afghanistan (1959-1966). Trans. Am. Phil. Soc. 62, 5-13. 
Dupree, L.,Davis, R.S., 1972. The lithic and bone specimens from Aq Kupruk and Darra-ikur. In Dupree, L. (ed) Prehistoric research in Afghanistan (1959-1966). Trans. Am. Phil. Soc. 62, 14-32.

Fu, Q., Meyer, M., Gao, X., Stenzel, U., Burbano, H.A., Kelso, J., Pääbo, S., 2013a. DNA analysis of an early modern human from Tianyuan Cave, China. Proc. Natl. Acad. Sci. 110, 2223-2227.

Fu, Q., Mittnik, A., Johnson, P.L., Bos, K., Lari, M., Bollongino, R., Sun, C., Giemsch, L., Schmitz, R., Burger, J., Ronchitelli, A.M., Martini, F., Cremonesi, R.G., Svoboda, J., Bauer, P., Caramelli, D., Castellano, S., Reich, D., Pääbo, S., Krause, J., 2013b. A revised timescale for human evolution based on ancient mitochondrial genomes. Curr. Biol. 23, 553559.

Fu, Q., Li, H., Moorjani, P., Jay, F., Slepchenko, S.M., Bondarev, A.A., Johnson, P.L.F., AximuPetri, A., Prüfer, K., de Filippo, C., Meyer, M., Zwyns, N., Salazar-Garcia, D., Kuzmin, Y.V., Keates, S.G., Kosintsev, P.A., Razhev, D.I., Richards, M.P., Peristov, N.V., Lachmann, M., Douka, K., Higham, T.F.G., Slatkin, M., Hublin, J., Reich, D., Kelso, J., Viola, T.B., Paabo, S., 2014. Genome sequence of a 45,000-year-old modern human from western Siberia. Nature 514, 445-449.

Gamba, C., Jones, E.R., Teasdale, M.D., McLaughlin, R.L., Gonzalez-Fortes, G., Mattiangeli, V., Domboroczki, L., Kovari, I., Pap, I., Anders, A., Whittle, A., Dani, J., Raczky, P., Higham, T.F., Hofreiter, M., Bradley, D.G., Pinhasi, R., 2014. Genome flux and stasis in a five millennium transect of European prehistory. Nat. Commun. 5, 5257.

Gansauge, M.T., Meyer, M., 2013. Single-stranded DNA library preparation for the sequencing of ancient or damaged DNA. Nat. Protoc. 8, 737-748.

Glantz, M.M. 2010. The history of hominin occupation of Central Asia in review. In: Norton, C.J., Braun, D. (Eds.), Asian Paleoanthropology: from Africa to China and Beyond. Springer, Dordrecht, The Netherlands, pp. 101-112.

Glantz, M.M., Viola, B., Chikisheva, T., 2004. New hominid remains from Obi-Rakhmat Grotto. In: Derevianko, A.P. (Ed.), Grot Obi-Rakhmat. Novosibirsk: Institute of Archaeology and Ethnography, Siberian Branch, Russian Academy of Sciences, pp. 77-93.

Glantz, M., Athreya, S., Ritzman, T., 2008a. Is Central Asia the eastern outpost of the Neandertal range? A reassessment of the Teshik-Tash child. Am. J. Phys. Anthropol. $138,45-61$.

Glantz, M., Viola, B., Wrinn, P., Chikisheva, T., Derevianko, A., Krivoshapkin, A., Islamov, U., Suleimanov, R., Ritzman, T., 2008b. New hominin remains from Uzbekistan. J. Hum. Evol. 55, 223-237.

Gremiatsky MA. 1949. The skull of the Neandertal child from the cave of Teshik-Tash, southern Uzbekistan. In: Gremiatsky, M.A., Nesturkh, M.F. (Eds.), Teshik Tash: Paleolithic Man. Moscow State University, Moscow, pp. 137-182.

Harvati K., 2003. Quantitative analysis of Neanderthal temporal bone morphology using three-dimensional geometric morphometrics. Am. J. Phys. Anthropol. 120, 323-338.

Jaubert, J., Biglari, F., Bruxelles, L., Bordes, J.G., Shidrang, S., Naderi, R., Mashkour, M., Maureille, B., Mallye, J.B., Quinif, Y., Rendu, W., Laroulandie, V.,2006. The Middle Palaeolithic occupation of Mar-Tarik, a new Zagros Mousterian site in Bisotun Massif (Kermanshah, Iran). In; Otte, M., Boglari, F., Jaubert, J (Eds.), Iran Palaeolithic/Le Paléolithique d'Iran. Proceedings of the XV World Congress (Lisbon, 4-9 September 2006) Volume 28. Archaeopress, Oxford, pp. 7-27. 
Kennedy, K.A.R., 2007. The Narmada fossil hominid. In: Sankhyan, A.R., Rao, V.R. (Eds.), Human Origins, Genome and People of India: Genomic, Palaeontological and Archaeological Perspectives., Allied, New Delhi, Pp. 188-192.

Kircher, M., Sawyer, S., Meyer, M., 2012. Double indexing overcomes inaccuracies in multiplex sequencing on the Illumina platform. Nucleic Acids Res. 40, e3.

Kolobova K.A., Flas D., Derevianko A.P., Pavlenok K.K., Islamov U.I., Kri- voshapkin, A.I., 2013. The Kulbulak bladlet tradition of the Upper Paleolithic in Central Asia. Archaeology, Ethnology and Anthropology of Eurasia 41, 2-25.

Korlević, P., Gerber, T., Gansauge, M.T., Hajdinjak, M., Nagel, S., Aximu-Petri, A., Meyer, M., 2015. Reducing microbial and human contamination in DNA extractions from ancient bones and teeth. BioTechniques 59, 87-93.

Krause, J., Orlando, L., Serre, D., Viola, B., Prüfer, K., Richards, M.P., Hublin, J.J., Hänni, C., Derevianko, A.P., Pääbo, S., 2007. Neanderthals in Central Asia and Siberia. Nature 449, 902-904.

Krause, J., Briggs, A.W., Kircher, M., Maricic, T., Zwyns, N., Derevianko, A., Pääbo, S., 2010. A complete mtDNA genome of an early modern human from Kostenki, Russia. Curr. Biol. 20, 231-236.

Lightfoot, E., Motuzaite-Matuzeviciute, G., O'Connell, T.C., Kukushkin, I.A., Loman, V., Varfolomeev, V., Liu, X., Jones, M.K., 2015. How 'pastoral' is pastoralism? Dietary diversity in Bronze Age communities in the Central Kazakhstan steppes. Archaeometry 57, 232-249.

Lindly, J.M., Clark, G.A., 1990. Symbolism and modern human origins. Curr. Anthropol. 31, 233-261.

Loogvali, E.L., Roostalu, U., Malyarchuk, B.A., Derenko, M.V., Kivisild, T., Metspalu, E., Tambets, K., Reidla, M., Tolk, H.V., Parik, J., Pennarun, E., Laos, S., Lunkina, A., Golubenko, M., Barac, L., Pericic, M., Balanovsky, O.P., Gusar, V., Khusnutdinova, E.K., Stepanov, V., Puzyrev, V., Rudan, P., Balanovska, E.V., Grechanina, E., Richard, C., Moisan, J.P., Chaventre, A., Anagnou, N.P., Pappa, K.I., Michalodimitrakis, E.N., Claustres, M., Golge, M., Mikerezi, I., Usanga, E., Villems, R., 2004. Disuniting uniformity: a pied cladistic canvas of mtDNA haplogroup H in Eurasia. Mol. Biol. Evol. 21, 2012-2021.

Malassé, A.D., Gaillard, C., 2011. Relations between climatic changes and prehistoric human migrations during Holocene between Gissar Range, Pamir, Hindu Kush and Kashmir: The archaeological and ecological data. Quatern. Int. 229, 123-131.

Maricic, T., Whitten, M., Pääbo, S., 2010. Multiplexed DNA Sequence Capture of Mitochondrial Genomes Using PCR Products. PLOS ONE 5(11): e14004. doi: 10.1371/journal.pone.0014004

Mednikova, M.B. 2013. An archaic human ulna from Chagyrskaya Cave Altai: Morphology and Taxonomy. Archaeology, Ethnology and Anthropology of Eurasia 41, 66-77.

Meyer, M., Fu, Q., Aximu-Petri, A., Glocke, I., Nickel, B., Arsuaga, J.L., Martinez, I., Gracia, A., Bermúdez de Castro, J.M., Carbonell, E., Pääbo, S., 2014. A mitochondrial genome sequence of a hominin from Sima de los Huesos. Nature 505, 403-406.

Pinhasi, R., Fernandes, D., Sirak, K., Novak, M., Connell, S., Alpaslan-Roodenberg, S., Gerritsen, F., Moiseyev, V., Gromov, A., Raczky, P., Anders, A., Pietrusewsky, M., Rollefson, G., Jovanovic, M., Trinhhoang, H., Bar-Oz, G., Oxenham, M., Matsumura, H., Hofreiter, M., 2015. Optimal ancient DNA yields from the inner ear part of the human petrous bone. PLOS ONE 10, e0129102. 
Prüfer, K., Racimo, F., Patterson, N., Jay, F., Sankararaman, S., Sawyer, S., Heinze, A., Renaud, G., Sudmant, P.H., de Filippo, C., Li, H., Mallick, S., Dannemann, M., Fu, Q., Kircher, M., Kuhlwilm, M., Lachmann, M., Meyer, M., Ongyerth, M., Siebauer, M., Theunert, C., Tandon, A., Moorjani, P., Pickrell, J., Mullikin, J.C., Vohr, S.H., Green, R.E., Hellmann, I., Johnson, P.L.F., Blanche, H., Cann, H., Kitzman, J.O., Shendure, J., Eichler, E.E., Lein, E.S., Bakken, T.E., Golovanova, L.V., Doronichev, V.B., Shunkov, M.V., Derevianko, A.P., Viola, B., Slatkin, M., Reich, D., Kelso, J. \& Paabo, S. 2014. The complete genome sequence of a Neanderthal from the Altai Mountains. Nature, 505, 7481, 43-49.

Quam, R., Martínez, I., Arsuaga, J.L., 2013. Reassessment of the La Ferrassie 3 Neandertal ossicular chain. J. Hum. Evol. 64, 250-262.

Ranov, V., Kolobova, K.A., Krivoshapkin, A.I., 2012. The Upper Paleolithic assem- blages of Shugnou, Tajikistan. Archaeology, Ethnology and Anthropology of Eurasia 40, 2-24.

Reimer, P.J., Bard, E., Bayliss, A., Beck, J.W., Blackwell, P.G., Bronk Ramsey, C., Buck, C.E., Cheng, H., Edwards, R.L., Friedrich, M., Grootes, P.M., Guilderson, T.P., Haflidason, H., Hajdas, I., Hatté, C., Heaton, T.J., Hoffmann, D.L., Hogg, A.G., Hughen, K.A., Kaiser, K.F., Kromer, B., Manning, S.W., Niu, M., Reimer, R.W., Richards, D.A., Scott, E.M., Southon, J.R., Staff, R.A., Turney, C.S.M., van der Plicht, J., 2013. IntCal13 and Marine13 radiocarbon age calibration curves 0-50,000 years cal BP. Radiocarbon 55, 18691887.

Renaud, G., Slon, V., Duggan, A.T., Kelso, J., 2015. Schmutzi: estimation of contamination and endogenous mitochondrial consensus calling for ancient DNA. Genome Biol. 16, 224.

Reyes-Centeno, H., 2016. Out of Africa and into Asia: Fossil and genetic evidence on modern human origins and dispersals. Quatern. Int. 416, 249-262

Sawyer, S., Krause, J., Guschanski, K., Savolainen, V., Pääbo, S., 2012. Temporal patterns of nucleotide misincorporations and DNA fragmentation in ancient DNA. PLoS ONE 7, e34131.

Slon, V., Glocke, I., Barkai, R., Gopher, A., Hershkovitz, I., Meyer, M., 2016. Mammalian mitochondrial capture, a tool for rapid screening of DNA preservation in faunal and undiagnostic remains, and its application to Middle Pleistocene specimens from Qesem Cave (Israel). Quatern. Int. 398, 210-218.

Sonakia, A., de Lumley, H. 2006. Narmada Homo erectus - A possible ancestor of the modern Indian. C. R. Palevo, 5, 353-357.

Spoor, F., Hublin J.J., Braun, M., Zonneveld, F., 2003. The bony labyrinth of Neanderthals. J. Hum Evol. 44, 141-165.

Street, M., Terberger, T., Orschiedt, J., 2006. A critical review of the German Paleolithic hominin record. J. Hum. Evol. 51, 551-579.

Stringer, C.B., Burleigh, R., 1981. The Neanderthal problem and the prospects for direct dating of Neanderthal remains. Bull. Br. Mus. Nat. Hist. (Geol.) 35, 225-241.

Talamo, S., Hajdinjak, M., Mannino, M.A., Fasani, L., Welker, F., Martini, F., Romagnoli, F., Zorzin, R., Meyer, M.,Hublin, J.-J., 2016. Direct radiocarbon dating and genetic analyses on the purported Neanderthal mandible from the Monti Lessini (Italy). Scientific Reports 6, 29144.

Trinkaus, E., Ranov, V.A., Laukhin, S., 2000. Middle Paleolithic human deciduous incisor from Khudji, Tajikistan. J. Hum. Evol. 38, 575-583.

Trinkaus E., 2005. Early modern humans. Ann. Rev. Anthropol. 34, 207-230.

Vishnyatsky, L.B., 1999. The Paleolithic of Central Asia. J. World Prehist. 13, 69-122. 


\section{Figures}

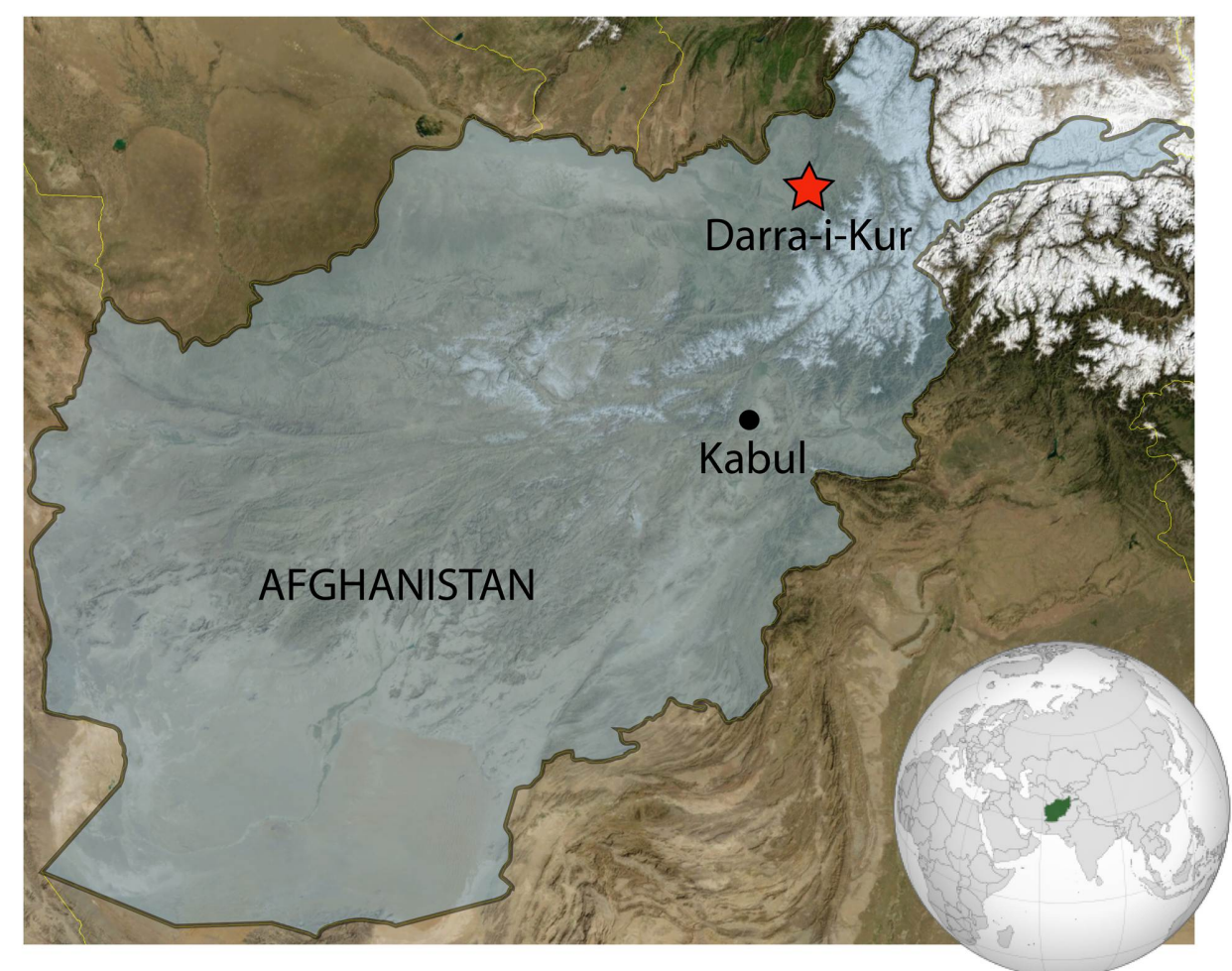

Figure 1. Map of Afghanistan showing the location of Darra-i-Kur in the northeastern part of the country (Badakhshan province).

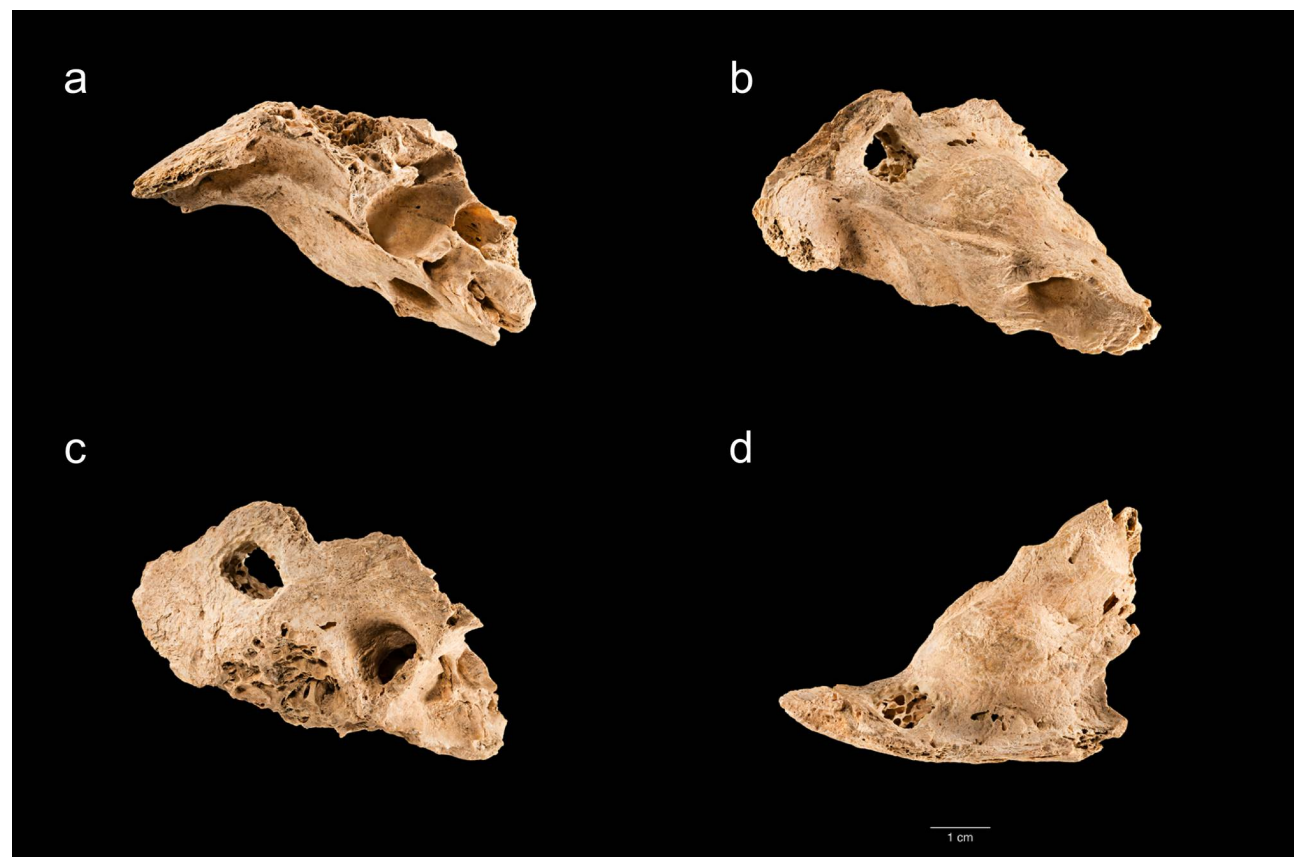

Figure 2. High resolution photographs of the Darra-i-Kur human temporal bone, now housed at the Smithsonian National Museum of Natural History (catalog number NMNH 387961). Copyright Smithsonian NMNH. (a) Inferior view; (b) internal view; (c) Right lateral view; (d) Superior view. (Photo credit: James DiLoreto, NMNH) 

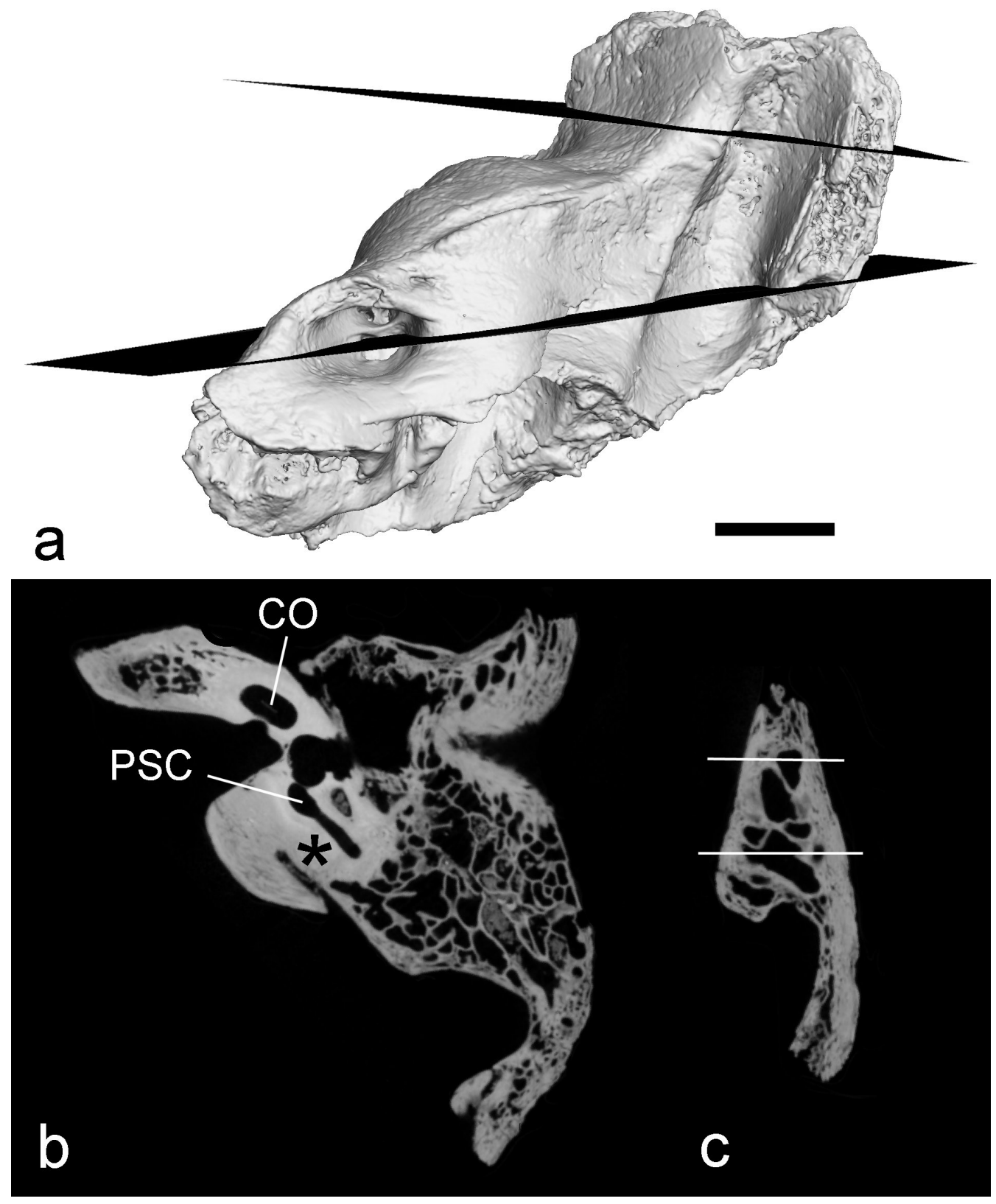

Figure 3. CT-based visualization of the Darra-i-Kur temporal bone. (a) Three-dimensional reconstruction with the cross-sections shown in (b) and (c). (b) CT image showing where sample A (asterisk) was taken medioposteriorly to the inferior limb of the posterior semicircular canal (PSC) and drilling superiorly from the jugular fossa underneath; the top of the cochlea (CO) is shown as well. (c) CT image through the squama with lines marking the area where sample B was taken. Scale bar $10 \mathrm{~mm}$. 
a

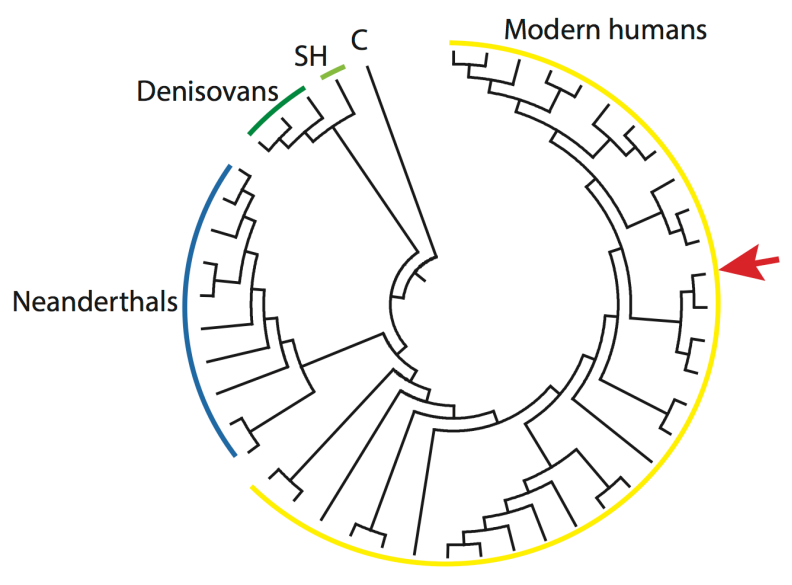

b

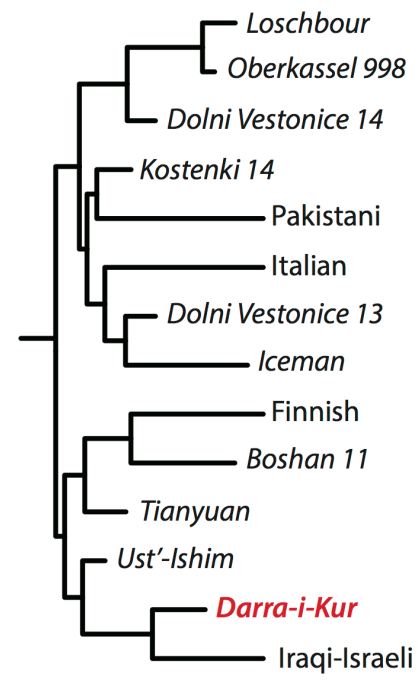

50000.0

Figure 4. The mtDNA sequence of the Darra-i-Kur specimen. (a) Maximum likelihood phylogenetic tree showing that the Darra-i-Kur mtDNA sequence (red arrow) falls within the variation of ancient and present-day modern humans, to the exclusion of Neanderthals, Denisovans and a Middle Pleistocene hominin (Sima de los Huesos [SH]). The tree is rooted using the chimpanzee (C) mtDNA genome. (b) Excerpt from a Bayesian phylogenetic tree used for dating the Darra-i-Kur tip. Branch lengths are scaled by number of years, and ancient individuals are noted in italics. 


\title{
SUPPLEMENTARY ONLINE MATERIAL
}

\section{Direct radiocarbon dating and DNA analysis of the Darra-i-Kur (Afghanistan) human temporal bone}

\author{
DNA analysis
}

Raw data processing

Sequencing was performed on a MiSeq sequencer (Illumina) using paired-end runs with parameters compatible with double-indexed libraries (2 X $76+7$ cycles) (Kircher et al., 2012). We used Bustard (Illumina) for base calling and leeHom (Renaud et al., 2014) to remove adapter sequences and merge overlapping forward and reverse reads. Only reads matching the expected double-index combinations were retained. Mapping to the human reference genome (UCSC version hg19) and to the revised Cambridge Reference Sequence (rCRS) of the mitochondrial genome was carried out using BWA (Li and Durbin, 2010) with parameters “-n 0.01 -o 2 -l 16500” adjusted for ancient DNA (Meyer et al., 2012). Nuclear sequences mapping outside an alignability track that excludes non-unique sequences (Prüfer et al., 2014) were discarded. Duplicated sequences were collapsed by bam-rmdup (https://bitbucket.org/ustenzel/biohazard). We used SAMtools (Li et al., 2009) to filter sequences based on length, mapping quality and/or the presence of nucleotide substitutions; and to merge sequence data originating from different sequencing runs. For all analyses, only sequences longer than 35 bases and with a mapping quality of at least 25 (Phred scale) were retained.

\section{Shotgun data}

Extrapolating DNA yields: We extrapolated the number of sequences that would be yielded and pass our filtering scheme if a library was sequenced to exhaustion using the following calculation: ((number of sequences mapped to the reference genome) / (overall number of sequences generated by sequencing) $\mathrm{X}$ (number of DNA molecules in the library as determined by digital droplet PCR). The resulting number was then normalized by the input amount of bone powder (in mg). 
Estimating contamination by female DNA: The identification of the Darra-i-Kur specimen as a male enables us to estimate the extent of contamination by female DNA in the data based on the excess of fragments mapping to the $\mathrm{X}$ chromosome (Sawyer et al., 2015). This was calculated as follows: ((observed number of sequences mapping to the $X$ chromosome) - (number of sequences expected to map to the X chromosome)) / (number of sequences expected to map to the $\mathrm{X}$ chromosome). The number of sequences expected to map to the $\mathrm{X}$ chromosome was computed as: (number of unique sequences mapping to the reference genome) $\mathrm{X}$ (number of bases within the alignability track on the $\mathrm{X}$ chromosome [86,251,694 bases]) / (number of bases within the alignability track in a male genome). When combining all sequences obtained from the Darra-i-Kur specimen, 327 fragments mapped to the $\mathrm{X}$ chromosome, whereas only 278 such fragments were expected, resulting in a female contamination estimate of $17.6 \%$. After retaining only sequences with a terminal $\mathrm{C}$ to $\mathrm{T}$ substitution, 14 fragments mapped to the $\mathrm{X}$ chromosome while only 13 fragments were expected ( $7.7 \%$ female contamination).

\section{Mitochondrial capture data}

Reconstructing the Darra-i-Kur mtDNA: Two approaches were taken to determine the mtDNA sequence of the Darra-i-Kur individual. First, we combined the sequences from the two libraries enriched for mtDNA fragments and retained only those showing a $\mathrm{C}$ to $\mathrm{T}$ substitution to the rCRS at their 5'- or 3'-end. To prevent such damage from influencing downstream analyses, Ts at the first three and last three positions of each sequence were masked where the reference genome carries a C (Meyer et al., 2014). 3,145 mtDNA fragments were retained, yielding an average coverage of 10.1-fold. We used the 'mpileup' function of SAMtools (Li et al., 2009) to determine for each position in the mtDNA genome the number of overlapping sequences and the bases they carry. We then called a consensus base by majority vote if a position was covered by a minimum of five sequences out of which at least $80 \%$ carried an identical base (Meyer et al., 2014). Using this approach, 1,664 bases could not be called. We carried out a preliminary phylogenetic analysis where this partial mtDNA sequence was compared to the mtDNAs of present-day humans and archaic hominins (Table S3). The partial mtDNA sequence of Darra-i-Kur falls within the variation of modern humans, to the exclusion of other hominin groups (Figure S2). 
Second, we called a consensus using schmutzi (Renaud et al., 2015), an iterative software that separates endogenous DNA fragments and present-day contamination based on the length of sequences and the presence of terminal nucleotide substitutions typical of ancient DNA. This was carried out using all 47,386 sequences generated by capture for mitochondrial DNA fragments, yielding an average mtDNA coverage of 181.9-fold. Using this approach, all bases in the mtDNA genome were called, and the resulting mtDNA sequence falls within modern human variation (Figure S2). The mtDNA consensus sequences generated by the two approaches differed at two positions (bases 73 and 7028 of the rCRS), which were converted to Ns in the final reconstruction of the Darra-i-Kur mtDNA sequence.

Estimating contamination by present-day human mtDNA: To estimate the extent of contamination by present-day human mtDNA in our mitochondrial capture data, we aligned the Darra-i-Kur mtDNA sequences to the mtDNAs of 311 present-day humans and identified three positions at which the former differs from $99 \%$ of the latter sequences (Green et al., 2008). 231 out of 277 sequences overlapping these positions carried a different base than the Darra-i-Kur consensus mtDNA, resulting in a contamination estimate of $83.4 \%$ (95\% CI: 78.5-87.6\%). The contamination estimates do not differ ( $p$ value $=0.9291)$ between mtDNA sequences from sample A $(83.7 \%$ contamination, $95 \% \mathrm{CI}$ : 78.4-88.1) and sample B (81.6\% contamination, 95\% CI: 65.7-92.3\%). When considering only sequences with a terminal $\mathrm{C}$ to $\mathrm{T}$ substitution, only one out of nine sequences disagrees with the consensus sequence (11.1\% contamination, 95\% CI: 0.03-48.2\%).

Phylogenetic analysis: The Darra-i-Kur mtDNA sequence was aligned to publicly available sequence data from present-day humans, archaic hominins and a chimpanzee (Table S3) using MAFFT (Katoh and Standley, 2013). To attribute the mtDNA to a hominin group, a phylogenetic tree was constructed using the maximum likelihood approach with 500 bootstrap replications in MEGA 6.0 (Tamura et al., 2013), using the TN93 substitution model (Tamura and Nei, 1993) with rate variation $(\Gamma+I)$ as determined using jModelTest2 (Darriba et al., 2012). The mitochondrial DNA haplogroup was identified using Haplogrep 2.0 (Kloss-Brandstatter et al., 2011) based on PhyloTree Build 17 (van Oven and Kayser, 2009). 
Molecular dating: We estimated the tip date of the specimen applying Bayesian phylogenetic inference using the program BEAST v1.8.0 (Drummond et al., 2012) and calibrated the phylogenetic tree using 10 directly-dated modern human samples (Table S3) (Fu et al., 2013b, 2014). Twenty present-day human mtDNA sequences were added to the alignment (Table S3) and a Neanderthal mtDNA (Vindija 33.16) was used as an outgroup. We determined the TN93 model (Tamura and Nei, 1993) with rate variation $(\Gamma+\mathrm{I})$ as the best substitution model for this alignment using jModelTest2 (Darriba et al., 2012). The tree model was set to "Coalescent: Constant Size" and we chose a strict clock as the clock model over a uncorrelated lognormally-distributed relaxed clock after performing Marginal Likelihood Estimation (Baele et al., 2012, 2013) and comparing the Bayes factors $(\log 10(B F)>111$, which is decisive based on the scale by Kass and Raftery, 1995). We ran 10 Markov Chain Monte Carlo runs with 10 million steps, sampling every 1,000 steps. Ten percent of the chains were removed as burn-in, both the log files and the tree files were combined, and a Maximum Clade Credibility tree was annotated. The resulting mean tip date for the Darra-i-Kur mtDNA is 16,716 years, with a 95\% highest posterior density (HPD) interval of 12-31,587 years. The HPD interval takes into account the confidence intervals of the mutation rate, uncertainties of the assignment of substitutions to each branch in the tree, differences in population size over time, and the confidence intervals of the radiocarbon dates for the ancient humans used as calibration points.

\section{Statistical analysis}

We tested for differences in the proportions of nucleotide substitutions and of contaminating sequences using the "prop.test" function in R. 
Table S1. Identifiers of extracts and DNA libraries prepared from the Darra-i-Kur specimen and the negative controls.

\begin{tabular}{|c|c|c|c|c|c|c|}
\hline Sample & Extract ID & Library ID & $\begin{array}{l}\text { Indexed } \\
\text { library ID }\end{array}$ & $\begin{array}{c}\text { Shotgun } \\
\text { sequencing } \\
\text { pool }\end{array}$ & $\begin{array}{l}\text { Captured } \\
\text { library ID }\end{array}$ & $\begin{array}{c}\text { Capture } \\
\text { sequencing } \\
\text { pool }\end{array}$ \\
\hline A (petrous part) & E2438 & L5066 & L5082 & \multirow{4}{*}{ L5111 } & L5098 & \multirow{4}{*}{ L5113 } \\
\hline ENC-A1 & E2439 & L5067 & L5083 & & L5099 & \\
\hline ENC-A2 & E2440 & L5068 & L5084 & & L5100 & \\
\hline LNC-A & - & L5078 & L5094 & & L5109 & \\
\hline B (squama) & E3034 & L5357 & L5385 & \multirow{3}{*}{ L5406 } & L5407 & \multirow{3}{*}{ L5426 } \\
\hline ENC-B & E3037 & L5360 & L5388 & & L5410 & \\
\hline LNC-B & - & L5372 & L5400 & & L5413 & \\
\hline
\end{tabular}

ENC - extraction negative control; LNC - library negative control 
Table S2. Sequencing results obtained from the Darra-i-Kur specimen and the negative controls.

\begin{tabular}{|c|c|c|c|c|c|c|c|c|c|c|c|c|c|c|c|c|}
\hline \multirow[b]{2}{*}{ Sample } & \multirow[b]{2}{*}{$\begin{array}{l}\text { Bone } \\
\text { powder } \\
\text { [mg] }\end{array}$} & \multirow[b]{2}{*}{$\begin{array}{l}\text { Number of } \\
\text { molecules }\end{array}$} & \multirow[b]{2}{*}{$\begin{array}{l}\text { Number of } \\
\text { sequences }\end{array}$} & \multirow[b]{2}{*}{$\begin{array}{c}\text { Number of } \\
\text { sequences } \\
\text { longer } \\
\text { than } 35 \\
\text { bases }\end{array}$} & \multicolumn{6}{|c|}{ All sequences } & \multicolumn{6}{|c|}{ Sequences with a $5^{\prime}$ or $3^{\prime} \mathrm{C}$ to $\mathrm{T}$ substitution } \\
\hline & & & & & $\begin{array}{c}\text { Mapped } \\
\text { sequences }\end{array}$ & $\begin{array}{c}\text { Mapped } \\
\text { sequences } \\
{[\%]}\end{array}$ & $\begin{array}{l}\text { Extrapol. } \\
\text { number of } \\
\text { retained } \\
\text { sequences } \\
\text { per mg of } \\
\text { bone }\end{array}$ & $\begin{array}{l}5{ }^{\prime} \mathrm{C} \text { to } \mathrm{T} \\
\text { [\%] (obs.) }\end{array}$ & $\begin{array}{c}3^{\prime} \mathrm{C} \text { to } \mathrm{T} \\
{[\%] \text { (obs.) }}\end{array}$ & $\begin{array}{c}\text { Average } \\
\text { sequence } \\
\text { length } \\
\text { [bp] }\end{array}$ & $\begin{array}{c}\text { Mapped } \\
\text { sequences }\end{array}$ & $\begin{array}{c}\text { Mapped } \\
\text { sequences } \\
{[\%]}\end{array}$ & $\begin{array}{l}\text { Extrapol. } \\
\text { number of } \\
\text { retained } \\
\text { sequences } \\
\text { per mg of } \\
\text { bone }\end{array}$ & $\begin{array}{c}5^{\prime} \mathrm{C} \text { to } \mathrm{T} \\
{[\%]} \\
\text { (obs.) }\end{array}$ & $\begin{array}{c}3 \text { C to } \mathrm{T} \\
{[\%]} \\
\text { (obs.) }\end{array}$ & $\begin{array}{c}\text { Average } \\
\text { sequence } \\
\text { length } \\
\text { [bp] }\end{array}$ \\
\hline $\begin{array}{l}\text { A } \\
\text { (petrous) }\end{array}$ & 15.2 & $1.25 \mathrm{E}+10$ & $1,814,213$ & $1,083,125$ & 8,662 & 0.80 & $3.93 \mathrm{E}+06$ & $\begin{array}{c}16.1 \\
(249 / 1,546)\end{array}$ & $\begin{array}{c}17.4 \\
(237 / 1,361)\end{array}$ & 58.2 & 466 & 0.043 & $2.11 \mathrm{E}+05$ & $\begin{array}{c}34.5 \\
(20 / 58)\end{array}$ & $\begin{array}{c}40.8 \\
(20 / 49)\end{array}$ & 50.1 \\
\hline ENC-A1 & & $2.16 \mathrm{E}+08$ & 422,966 & 270,123 & 9,483 & 3.51 & $3.18 \mathrm{E}+05$ & $\begin{array}{c}0.3 \\
(4 / 1,347)\end{array}$ & $\begin{array}{c}0.7 \\
(9 / 1,257)\end{array}$ & 65.0 & 13 & 0.005 & 436 & $\begin{array}{c}0.0 \\
(0 / 1)\end{array}$ & $\begin{array}{c}0.0 \\
(0 / 1)\end{array}$ & 71.5 \\
\hline ENC-A2 & & $2.19 \mathrm{E}+08$ & 239,113 & 124,075 & 5,142 & 4.14 & $3.09 \mathrm{E}+05$ & $\begin{array}{c}0.6 \\
(5 / 836)\end{array}$ & $\begin{array}{c}0.4 \\
(3 / 745)\end{array}$ & 64.8 & 8 & 0.006 & 481 & $\begin{array}{l}\mathrm{N} / \mathrm{A} \\
(0 / 0)\end{array}$ & $\begin{array}{l}\text { N/A } \\
(0 / 0)\end{array}$ & 78.1 \\
\hline LNC-A & & $2.17 \mathrm{E}+08$ & 266,740 & 146,513 & 92 & 0.06 & $4.92 \mathrm{E}+03$ & $\begin{array}{c}0.0 \\
(0 / 22)\end{array}$ & $\begin{array}{c}0.0 \\
(0 / 17)\end{array}$ & 48.6 & 0 & 0 & 0 & $\begin{array}{l}\mathrm{N} / \mathrm{A} \\
(0 / 0)\end{array}$ & $\begin{array}{l}\text { N/A } \\
(0 / 0)\end{array}$ & N/A \\
\hline $\begin{array}{l}\text { B } \\
\text { (squama) }\end{array}$ & 17.0 & $8.50 \mathrm{E}+09$ & $6,914,215$ & $4,283,806$ & 4,901 & 0.11 & $3.54 \mathrm{E}+05$ & $\begin{array}{c}5.0 \\
(42 / 845)\end{array}$ & $\begin{array}{c}7.1 \\
(48 / 676)\end{array}$ & 60.0 & 89 & 0.002 & $6.44 \mathrm{E}+03$ & $\begin{array}{l}12.5 \\
(1 / 8)\end{array}$ & $\begin{array}{l}14.3 \\
(1 / 7)\end{array}$ & 54.2 \\
\hline ENC-B & - & $9.30 \mathrm{E}+07$ & 623,428 & 386,868 & 1,162 & 0.30 & $1.02 \mathrm{E}+04$ & $\begin{array}{c}0.0 \\
(0 / 193)\end{array}$ & $\begin{array}{c}1.2 \\
(2 / 169)\end{array}$ & 60.7 & 2 & 0.001 & 18 & $\begin{array}{l}0.0 \\
(0 / 1)\end{array}$ & $\begin{array}{l}\text { N/A } \\
(0 / 0)\end{array}$ & 81.0 \\
\hline LNC-B & - & $2.87 \mathrm{E}+07$ & 975,660 & 827,177 & 441 & 0.05 & 763 & $\begin{array}{c}1.0 \\
(1 / 103)\end{array}$ & $\begin{array}{c}3.3 \\
(2 / 61)\end{array}$ & 47.1 & 3 & 0.000 & 5 & $\begin{array}{l}0.0 \\
(0 / 1)\end{array}$ & $\begin{array}{l}\text { N/A } \\
(0 / 0)\end{array}$ & 40.0 \\
\hline
\end{tabular}

C - cytosine; T - thymine; ENC - extraction negative control; LNC - library preparation negative control; Extrapol. - Extrapolated; obs. observations; N/A - not available. Mapped sequences refer to sequences longer than 35 bases that map within the alignability track of the human reference genome with a mapping quality higher than 25 . The percentage of mapped sequences was calculated out of 
Table S3. Comparative mitochondrial (mt) DNA sequence data used in the phylogenetic analyses.

\begin{tabular}{|c|c|c|c|}
\hline Ancient mtDNA sequences & $\begin{array}{c}\text { Accession } \\
\text { code }\end{array}$ & Present-day mtDNA sequences & $\begin{array}{c}\text { Accession } \\
\text { code }\end{array}$ \\
\hline \multicolumn{2}{|l|}{ Ancient modern humans } & \multicolumn{2}{|l|}{ Present-day modern humans } \\
\hline Boshan 11 (China) [1] & KC521454 & Australian [2] & AY289066 \\
\hline Dolni Vestonice 13 (Czech Republic) [1] & KC521459 & Caucasian [3] & AY195774 \\
\hline Dolni Vestonice 14 (Czech Republic) ${ }^{[1]}$ & KC521458 & Chinese [4] & AF346973 \\
\hline Iceman (Austro-Italian border) [5] & EU810403 & Filipino [2] & AY289070 \\
\hline Kostenki 14 (Russia) [6] & FM600416 & Finnish [3] & AY195773 \\
\hline Loschbour (Luxembourg) [1] & KC521455 & German [4] & AF346983 \\
\hline Oberkassel 998 (Germany) ${ }^{[1]}$ & KC521457 & Indian $[4]$ & AF346966 \\
\hline Saqqaq (Greenland) [7] & EU725621 & Iraqi-Israeli [3] & AY195757 \\
\hline Tianyuan (China) [8] & KC417443 & Italian [9] & AY882393 \\
\hline Ust'-Ishim (Siberia) [10] & PRJEB6622 & Jordanian [11] & AF381998 \\
\hline \multicolumn{2}{|l|}{ Neanderthals } & Mandenka [4] & AF346995 \\
\hline Altai (Siberia) [12] & KC879692 & Mbuti [4] & AF346999 \\
\hline El Sidron 1253 (Spain) [13] & FM865409 & Mixteca-Baja [3] & AY195786 \\
\hline Feldhofer 1 (Germany) [13] & FM865407 & Mkamba [4] & $\mathrm{AF} 347000$ \\
\hline Feldhofer 2 (Germany) [13] & FM865408 & Native American [3] & AY195759 \\
\hline Mezmaiskaya 1 (Caucasus) [13] & FM865411 & Pakistani [9] & AY882380 \\
\hline Okladnikov 2 (Siberia) [14] & KF982693 & Papua New Guinean (Highland) [2] & AY289085 \\
\hline Vindija 33.16 (Croatia) [15] & AM948965 & San [4] & AF347008 \\
\hline Vindija 33.17 (Croatia) [16] & KJ533544 & Taiwanese Indian [2] & AY289098 \\
\hline Vindija 33.19 (Croatia) [16] & KJ533545 & Yoruba [4] & AF347015 \\
\hline Vindija 33.25 (Croatia) [13] & FM865410 & Chimpanzee [17] & NC001643 \\
\hline \multicolumn{2}{|l|}{ Denisovans } & & \\
\hline Denisova 3 (Siberia) [18] & NC013993 & & \\
\hline Denisova 4 (Siberia) ${ }^{[19]}$ & FR695060 & & \\
\hline Denisova 8 (Siberia) [20] & KT780370 & & \\
\hline \multicolumn{2}{|l|}{ Middle Pleistocene hominin } & & \\
\hline Sima de los Huesos (Spain) [21] & NC023100 & & \\
\hline
\end{tabular}

Comparative sequence data was taken from [1] Fu et al., 2013b; [2] Ingman and Gyllensten, 2003; [3] Mishmar et al., 2003; [4] Ingman et al., 2000; [5] Ermini et al., 2008; [6] Krause et al., 2010a; [7] Gilbert et al., 2008; [8] Fu et al., 2013a; [9] Achilli et al., 2005; [10] Fu et al., 2014; [11] Maca-Meyer et al., 2001; [12] Prüfer et al., 2014; [13] Briggs et al., 2009; [14] Skoglund et al., 2014; [15] Green et al., 2008; [16] Gansauge and Meyer, 2014; [17] Horai et al., 1995; [18] Krause et al., 2010b; [19] Reich et al., 2010; [20] Sawyer et al., 2015; [21] Meyer et al., 2014. 


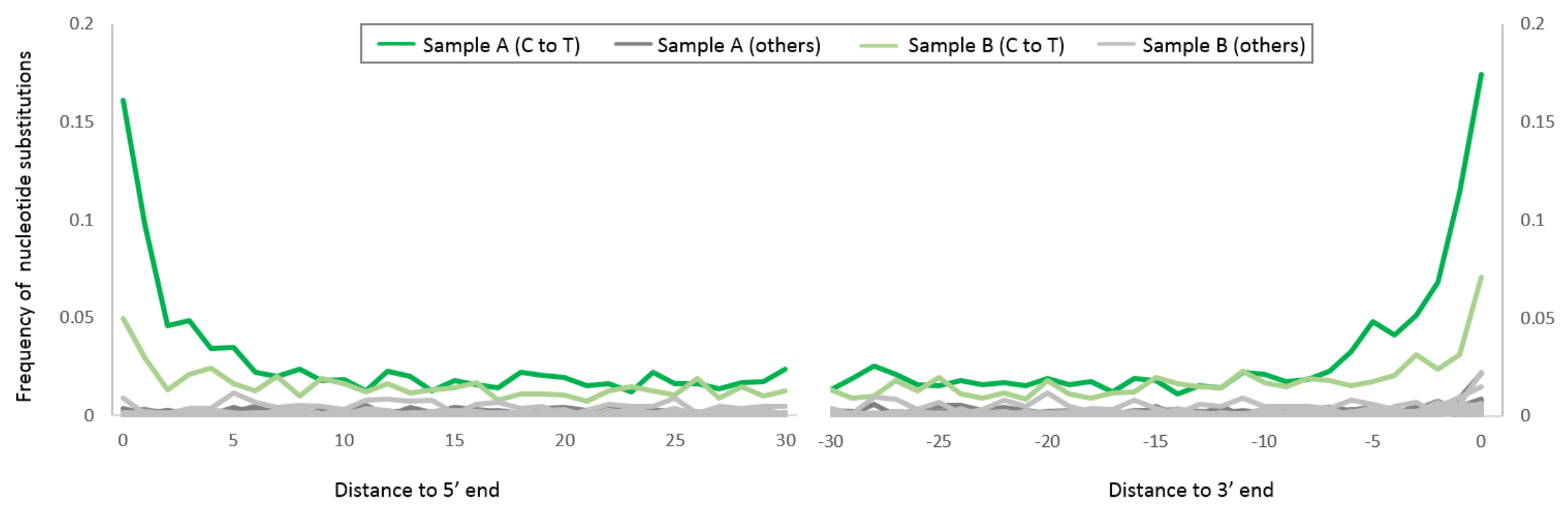

Figure S1. Frequency of nucleotide substitutions in the libraries prepared from the Darra-i-Kur temporal bone. In both libraries, the cytosine (C) to thymine (T) substitutions (green) are elevated compared to any other type of base substitution (gray) at and near the end of DNA fragments, indicating the preservation of ancient DNA molecules in the specimen. The frequency of terminal $C$ to $T$ substitutions is significantly higher in sequences originating from sample $A$ than in sequences from sample B (dark and light green, respectively). 


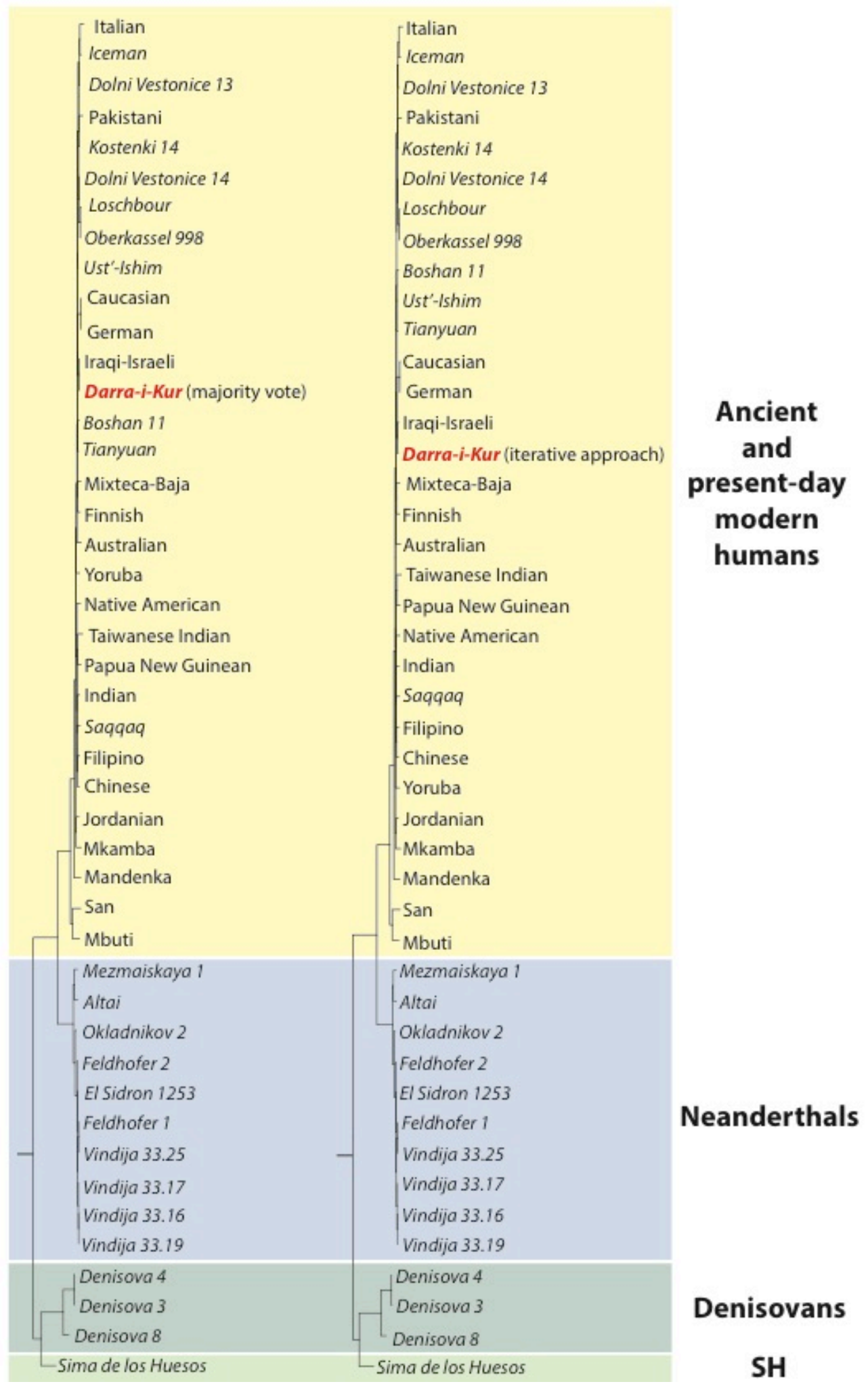

Figure S2. Preliminary phylogenetic analyses using mtDNA consensus sequences for Darra-i-Kur as reconstructed using two approaches. Both phylogenetic trees were constructed by the maximum likelihood method with 500 bootstrap replications, by comparing to the mtDNA sequences of 20 present-day humans, 10 ancient modern humans, 10 Neanderthals, three Denisovans and one Middle Pleistocene hominin (Table S3). A chimpanzee mtDNA used as an outgroup is not shown. Left: The preliminary mtDNA sequence of Darra-i-Kur was reconstructed using only fragments showing a cytosine to thymine substitution to the reference genome at their 5 ' - or 3 '-ends by majority vote while requiring a mininum coverage of 5 sequences and a mininum consensus support of $80 \%$. 
Right: The preliminary mtDNA sequence of Darra-i-Kur was reconstructed from all mtDNA fragments generated from this specimen, using an iterative approach to separate endogenous and contaminating DNA while taking into account sequence length and damage patterns typical of ancient DNA. 


\section{SOMN references}

Achilli, A., Rengo, C., Battaglia, V., Pala, M., Olivieri, A., Fornarino, S., Magri, C., Scozzari, R., Babudri, N., Santachiara-Benerecetti, A.S., Bandelt, H.J., Semino, O., Torroni, A., 2005. Saami and Berbers--an unexpected mitochondrial DNA link. Am. J. Hum. Genet. 76, 883-886.

Baele, G., Lemey, P., Bedford, T., Rambaut, A., Suchard, M.A., Alekseyenko, A.V., 2012. Improving the accuracy of demographic and molecular clock model comparison while accommodating phylogenetic uncertainty. Mol. Biol. Evol. 29, 2157-2167.

Baele, G., Li, W.L., Drummond, A.J., Suchard, M.A., Lemey, P., 2013. Accurate model selection of relaxed molecular clocks in Bayesian phylogenetics. Mol. Biol. Evol. 30, 239-243.

Briggs, A.W., Good, J.M., Green, R.E., Krause, J., Maricic, T., Stenzel, U., Lalueza-Fox, C., Rudan, P., Brajkovic, D., Kucan, Z., Gusic, I., Schmitz, R., Doronichev, V.B., Golovanova, L.V., de la Rasilla, M., Fortea, J., Rosas, A., Pääbo, S., 2009. Targeted retrieval and analysis of five Neandertal mtDNA genomes. Science 325, 318-321.

Darriba, D., Taboada, G.L., Doallo, R., Posada, D., 2012. jModelTest 2: more models, new heuristics and parallel computing. Nat. Methods 9, 772.

Drummond, A.J., Suchard, M.A., Xie, D., Rambaut, A., 2012. Bayesian phylogenetics with BEAUti and the BEAST 1.7. Mol. Biol. Evol. 29, 1969-1973.

Ermini, L., Olivieri, C., Rizzi, E., Corti, G., Bonnal, R., Soares, P., Luciani, S., Marota, I., De Bellis, G., Richards, M.B., Rollo, F., 2008. Complete mitochondrial genome sequence of the Tyrolean Iceman. Curr. Biol. 18, 1687-1693.

Fu, Q., Meyer, M., Gao, X., Stenzel, U., Burbano, H.A., Kelso, J., Pääbo, S., 2013a. DNA analysis of an early modern human from Tianyuan Cave, China. Proc. Natl. Acad. Sci. 110, 2223-2227.

Fu, Q., Mittnik, A., Johnson, P.L., Bos, K., Lari, M., Bollongino, R., Sun, C., Giemsch, L., Schmitz, R., Burger, J., Ronchitelli, A.M., Martini, F., Cremonesi, R.G., Svoboda, J., Bauer, P., Caramelli, D., Castellano, S., Reich, D., Pääbo, S., Krause, J., $2013 \mathrm{~b}$. A revised timescale for human evolution based on ancient mitochondrial genomes. Curr. Biol. 23, 553-559.

Fu, Q., Li, H., Moorjani, P., Jay, F., Slepchenko, S.M., Bondarev, A.A., Johnson, P.L., Aximu-Petri, A., Prüfer, K., de Filippo, C., Meyer, M., Zwyns, N., SalazarGarcia, D.C., Kuzmin, Y.V., Keates, S.G., Kosintsev, P.A., Razhev, D.I., Richards, M.P., Peristov, N.V., Lachmann, M., Douka, K., Higham, T.F., Slatkin, M., Hublin, J.J., Reich, D., Kelso, J., Viola, T.B., Pääbo, S., 2014. Genome sequence of a 45,000-yearold modern human from western Siberia. Nature 514, 445-449.

Gansauge, M.T., Meyer, M., 2014. Selective enrichment of damaged DNA molecules for ancient genome sequencing. Genome Res. 24, 1543-1549. 
Gilbert, M.T., Kivisild, T., Gronnow, B., Andersen, P.K., Metspalu, E., Reidla, M., Tamm, E., Axelsson, E., Gotherstrom, A., Campos, P.F., Rasmussen, M., Metspalu, M., Higham, T.F., Schwenninger, J.L., Nathan, R., De Hoog, C.J., Koch, A., Moller, L.N., Andreasen, C., Meldgaard, M., Villems, R., Bendixen, C., Willerslev, E., 2008. Paleo-Eskimo mtDNA genome reveals matrilineal discontinuity in Greenland. Science 320, 1787-1789.

Green, R.E., Malaspinas, A.S., Krause, J., Briggs, A.W., Johnson, P.L., Uhler, C., Meyer, M., Good, J.M., Maricic, T., Stenzel, U., Prufer, K., Siebauer, M., Burbano, H.A., Ronan, M., Rothberg, J.M., Egholm, M., Rudan, P., Brajkovic, D., Kucan, Z., Gusic, I., Wikstrom, M., Laakkonen, L., Kelso, J., Slatkin, M., Pääbo, S., 2008. A complete Neandertal mitochondrial genome sequence determined by highthroughput sequencing. Cell 134, 416-426.

Horai, S., Hayasaka, K., Kondo, R., Tsugane, K., Takahata, N., 1995. Recent African origin of modern humans revealed by complete sequences of hominoid mitochondrial DNAs. Proc. Natl. Acad. Sci. 92, 532-536.

Ingman, M., Gyllensten, U., 2003. Mitochondrial genome variation and evolutionary history of Australian and New Guinean aborigines. Genome Res. 13, 1600-1606.

Ingman, M., Kaessmann, H., Pääbo, S., Gyllensten, U., 2000. Mitochondrial genome variation and the origin of modern humans. Nature 408, 708-713.

Kass, R.E., Raftery, A.E., 1995. Bayes factors. J. Am. Stat. Assoc. 90, 773795.

Katoh, K., Standley, D.M., 2013. MAFFT multiple sequence alignment software version 7: improvements in performance and usability. Mol. Biol. Evol. $30,772-780$.

Kircher, M., Sawyer, S., Meyer, M., 2012. Double indexing overcomes inaccuracies in multiplex sequencing on the Illumina platform. Nucleic Acids Res. 40, e3.

Kloss-Brandstatter, A., Pacher, D., Schonherr, S., Weissensteiner, H., Binna, R., Specht, G., Kronenberg, F., 2011. HaploGrep: a fast and reliable algorithm for automatic classification of mitochondrial DNA haplogroups. Hum. Mutat. 32, 2532 .

Krause, J., Briggs, A.W., Kircher, M., Maricic, T., Zwyns, N., Derevianko, A., Pääbo, S., 2010a. A Complete mtDNA genome of an early modern human from Kostenki, Russia. Curr. Biol. 20, 231-236.

Krause, J., Fu, Q., Good, J.M., Viola, B., Shunkov, M.V., Derevianko, A.P., Pääbo, S., 2010b. The complete mitochondrial DNA genome of an unknown hominin from southern Siberia. Nature 464, 894-897. 
Li, H., Durbin, R., 2010. Fast and accurate long-read alignment with Burrows-Wheeler transform. Bioinformatics 26, 589-595.

Li, H., Handsaker, B., Wysoker, A., Fennell, T., Ruan, J., Homer, N., Marth, G., Abecasis, G., Durbin, R., 1000 Genome Project Data Processing Subgroup, 2009. The Sequence Alignment/Map format and SAMtools. Bioinformatics 25, 20782079.

Maca-Meyer, N., Gonzalez, A.M., Larruga, J.M., Flores, C., Cabrera, V.M., 2001. Major genomic mitochondrial lineages delineate early human expansions. BMC Genet. 2, 13.

Meyer, M., Fu, Q., Aximu-Petri, A., Glocke, I., Nickel, B., Arsuaga, J.L., Martinez, I., Gracia, A., Bermúdez de Castro, J.M., Carbonell, E., Pääbo, S., 2014. A mitochondrial genome sequence of a hominin from Sima de los Huesos. Nature 505, 403-406.

Mishmar, D., Ruiz-Pesini, E., Golik, P., Macaulay, V., Clark, A.G., Hosseini, S., Brandon, M., Easley, K., Chen, E., Brown, M.D., Sukernik, R.I., Olckers, A., Wallace, D.C., 2003. Natural selection shaped regional mtDNA variation in humans. Proc. Natl. Acad. Sci. 100, 171-176.

Prüfer, K., Racimo, F., Patterson, N., Jay, F., Sankararaman, S., Sawyer, S., Heinze, A., Renaud, G., Sudmant, P.H., de Filippo, C., Li, H., Mallick, S., Dannemann, M., Fu, Q., Kircher, M., Kuhlwilm, M., Lachmann, M., Meyer, M., Ongyerth, M., Siebauer, M., Theunert, C., Tandon, A., Moorjani, P., Pickrell, J., Mullikin, J.C., Vohr, S.H., Green, R.E., Hellmann, I., Johnson, P.L., Blanche, H., Cann, H., Kitzman, J.O., Shendure, J., Eichler, E.E., Lein, E.S., Bakken, T.E., Golovanova, L.V., Doronichev, V.B., Shunkov, M.V., Derevianko, A.P., Viola, B., Slatkin, M., Reich, D., Kelso, J., Pääbo, S., 2014. The complete genome sequence of a Neanderthal from the Altai Mountains. Nature 505, 43-49.

Reich, D., Green, R.E., Kircher, M., Krause, J., Patterson, N., Durand, E.Y., Viola, B., Briggs, A.W., Stenzel, U., Johnson, P.L., Maricic, T., Good, J.M., MarquesBonet, T., Alkan, C., Fu, Q., Mallick, S., Li, H., Meyer, M., Eichler, E.E., Stoneking, M., Richards, M., Talamo, S., Shunkov, M.V., Derevianko, A.P., Hublin, J.J., Kelso, J., Slatkin, M., Pääbo, S., 2010. Genetic history of an archaic hominin group from Denisova Cave in Siberia. Nature 468, 1053-1060.

Renaud, G., Stenzel, U., Kelso, J., 2014. leeHom: adaptor trimming and merging for Illumina sequencing reads. Nucleic Acids Res. 42, e141.

Renaud, G., Slon, V., Duggan, A.T., Kelso, J., 2015. Schmutzi: estimation of contamination and endogenous mitochondrial consensus calling for ancient DNA. Genome Biol. 16, 224.

Sawyer, S., Renaud, G., Viola, B., Hublin, J.J., Gansauge, M.T., Shunkov, M.V., Derevianko, A., Prüfer, K., Kelso, J., Pääbo, S., 2015. Nuclear and mitochondrial DNA sequences from two Denisovan individuals. Proc. Natl. Acad. Sci. 112, 15696-15700. 
Skoglund, P., Northoff, B.H., Shunkov, M.V., Derevianko, A.P., Pääbo, S., Krause, J., Jakobsson, M., 2014. Separating endogenous ancient DNA from modern day contamination in a Siberian Neandertal. Proc. Natl. Acad. Sci. 111, 2229-2234.

Tamura, K., Nei, M., 1993. Estimation of the number of nucleotide substitutions in the control region of mitochondrial DNA in humans and chimpanzees. Mol. Biol. Evol. 10, 512-526.

Tamura, K., Stecher, G., Peterson, D., Filipski, A., Kumar, S., 2013. MEGA6: Molecular Evolutionary Genetics Analysis version 6.0. Mol. Biol. Evol. 30, 27252729.

van Oven, M., Kayser, M., 2009. Updated comprehensive phylogenetic tree of global human mitochondrial DNA variation. Hum. Mutat. 30, E386-394. 